\title{
Ulnar Nerve Compression at the Elbow Caused by the Epitrochleoanconeus Muscle : A Case Report and Surgical Approach
}

\section{Epitrochleoanconeus Kası Kaynaklı Ulnar Sinirin Dirsek Bölgesinde Sıkışması: Olgu Sunumu ve Cerrahi Yaklaşım}

\author{
Ilker USCETIN, Derya BINGOL, Ozay OZKAYA, Cagdas ORMAN, Mithat AKAN \\ Okmeydanı Research and Training Hospital, Department of Plastic, Reconstructive and Aesthetic Surgery, Istanbul, Turkey
}

Corresponding Author: Derya BINGOL / E-mail: deryabingl@hotmail.com

\begin{abstract}
Cubital tunnel syndrome is the second most common peripheral nerve compression syndrome. It is the most common peripheral neuropathy of the ulnar nerve. The surgical treatment of the cubital tunnel syndrome is widely described in the literature, however the variations of the standard muscular anatomy in the medial humeral epicondyle region may create technical difficulties during surgical management. The epitrochleoanconeus muscle, which is an aberrant muscle of this region, is a rare cause of cubital tunnel syndrome. A case with ulnar nerve compression at the elbow caused by an uncommon etiological factor, hypertrophic epitrochleoanconeus muscle, and its surgical management is reported.
\end{abstract}

KEYWORDS: Cubital tunnel syndrome, Peripheral neuropathy, Ulnar nerve entrapment, Peripheral nerve compression, Epitrochleoanconeus muscle

öz

Kübital tünel sendromu, periferik sinir sıkışma sendromları içerisinde ikinci en sık görülen sendromdur. Ulnar sinirin en sık periferik nöropatisidir. Literatürde cerrahi tedavisi yaygın olarak tanımlanmıştır ancak medial humeral epikondil bölgesinin standart kas anatomisindeki varyasyonlar cerrahi girişim sırasında teknik zorluklara yol açabilmektedir. Bu bölgede yerleşen ve aberran bir kas olan epitrokleoankoneus kası, kübital tünel sendromunun nadir nedenlerinden biridir. Bu olguda, nadir bir etiyolojik etken olarak hipertrofik epitrokleoankoneus kasının sebep olduğu ulnar sinirin dirsekte tuzaklanması ve cerrahi yaklaşımı sunulmaktadır.

ANAHTAR SÖZCÜKLER: Kübital tünel sendromu, Periferik nöropati, Ulnar sinir tuzaklanması, Periferik sinir sıkışması, Epitrokleoankoneus kası

\section{INTRODUCTION}

Cubital tunnel syndrome is the second most common peripheral nerve compression syndrome $(3,16)$. It is the most common peripheral neuropathy of the ulnar nerve. It may occur as a result of ischemia or mechanical compression by repeated elbow flexion, post-traumatic scarring, anomalous musculature or direct compression although the exact cause may be difficult to identify (1). The surgical treatment of the cubital tunnel syndrome is widely described in the literature, however the variations of the standard muscular anatomy in the medial humeral epicondyle region may create technical difficulties during surgical management (7). The epitrochleoanconeus muscle, which is an aberrant muscle of this region, is a rare cause of cubital tunnel syndrome. The nomenclature of this muscle is varied in the literature and the terms anconeus-epitrochlearis, subanconeus, or accessory anconeus have also been used to denote the same muscle $(5,8,18)$.
A case with ulnar nerve compression at the elbow caused by an uncommon etiological factor, a hypertrophic epitrochleoanconeus muscle, and the surgical management is reported.

\section{CASE REPORT}

A 45-year-old male patient was admitted to our clinic with complaints of pain and numbness in both hands, more prominent in the left. His complaints had slowly developed over the last four years and increased over the past year. The history revealed that he had hypertension, diabetes mellitus, hyperlipidemia and coronary bypass surgery. On physical examination, carpal tunnel syndrome was primarily considered. Fullness in the ulnar region of both elbows, and $70^{\circ}$ limitation of supination of both forearms were remarkable features (Figure 1). Properly limited solid masses, $4 \times 3 \mathrm{~cm}$ in size were palpated subcutaneously in the ulnar region in both elbows. Dysmorphic facial appearance, mild low hairline and mild webbed neck were distinctive features on systemic 


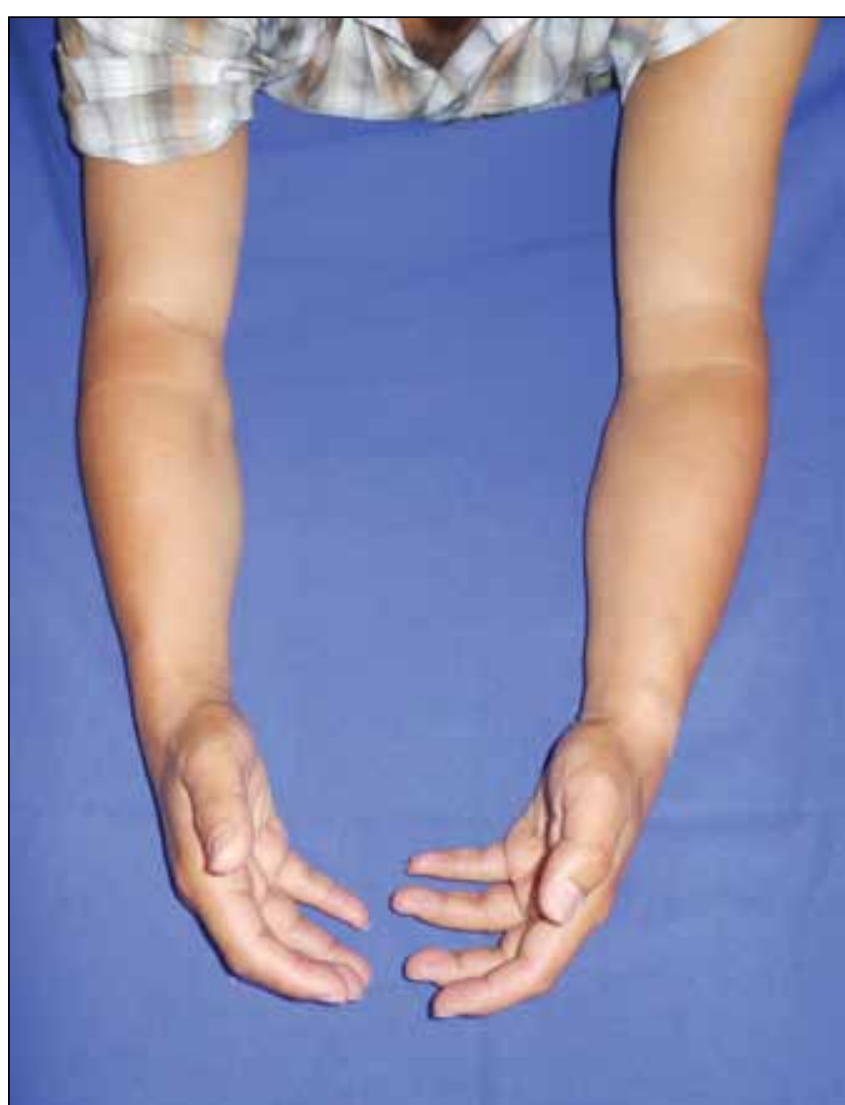

Figure 1: Bilateral fullness in the ulnar side of both elbows and limitation of the supination of bilateral forearms are seen. The patient is maximally supinating his forearms. examination (Figure 2). Electromyography of bilateral upper extremities revealed involvement of both the sensory and the motor fibers of the median nerve causing carpal tunnel syndrome moderately on the left side and mildly on the right side. The plain graphies of bilateral elbow regions performed to investigate the restriction of forearm supination revealed normal bony structures. Magnetic resonance imaging of bilateral elbows revealed aberrant masses of $4 \times 3 \mathrm{~cm}$ in size, located subcutaneously between the medial epicondyle and the olecranon and compatible with muscular tissue (Figure 3). The patient was examined by the genetic disorders consultant because of his distinctive features but his findings were not compatible with any syndrome. The patient was operated for carpal tunnel syndrome of both hands with an interval of 4 months. On the postoperative sixth month for the left hand, the symptoms had not disappeared and he described pain in his left elbow. On physical examination, he complained of pain and hypoaesthesia on the dermatome of the ulnar nerve of the left hand. Minimal hypothenar atrophy was observed with normal intrinsic muscular functions. Assessment of Tinel's sign and the compression test and the physical examination suggested left cubital tunnel syndrome. Electromyography of the left upper extremity was repeated and revealed that the conduction velocity of the sensory fibers of the median nerve had partially recovered in comparison with the previous one. It also revealed left ulnar nerve compression $1 \mathrm{~cm}$ distal to the medial epicondyle region causing minimal myelin degeneration of the motor fibers. The patient underwent surgery with a diagnosis of left cubital tunnel syndrome.

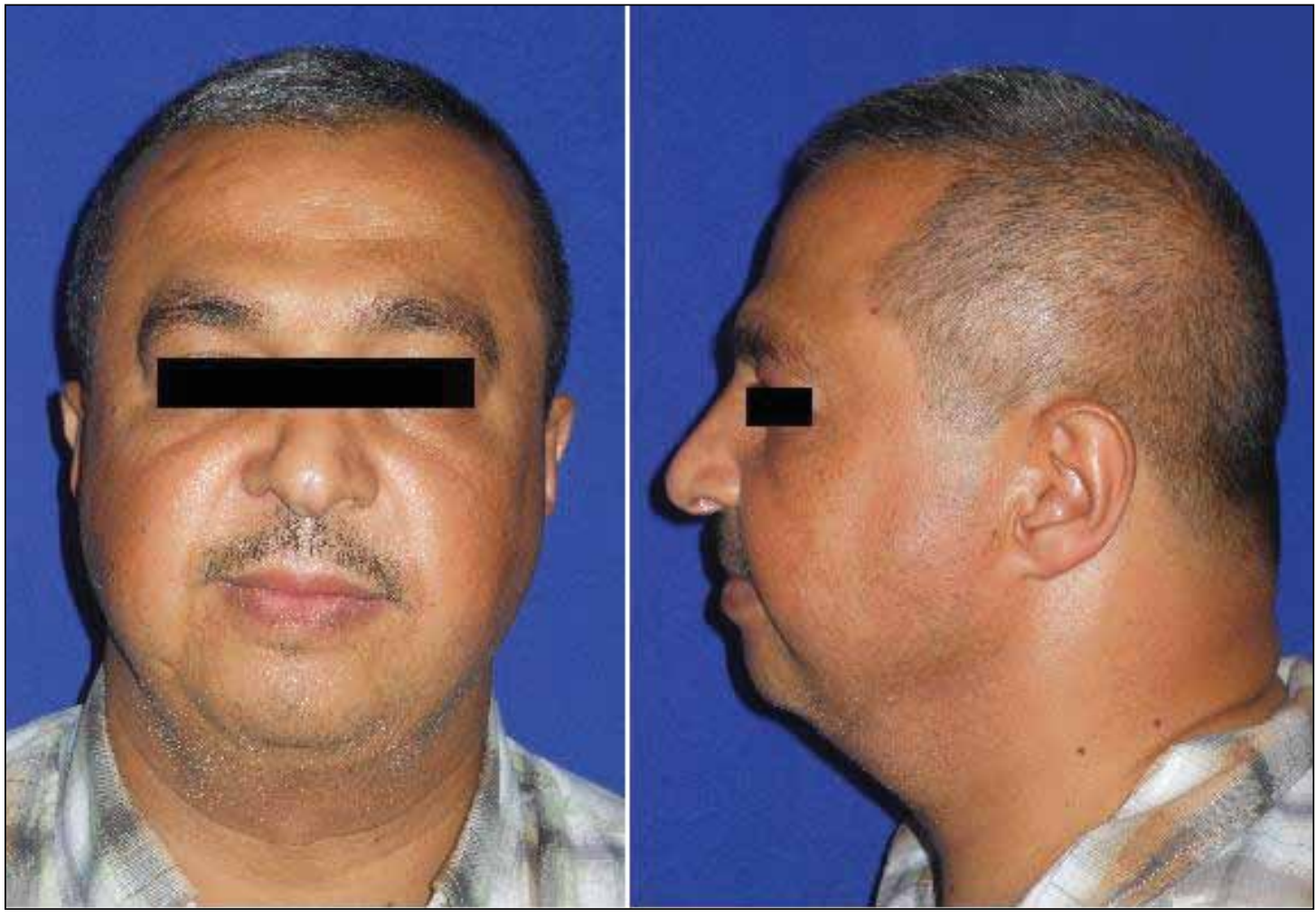

Figure 2: Anterior and lateral view of the patient showing dysmorphic facial appearance, mild low hairline and mild webbed neck. 


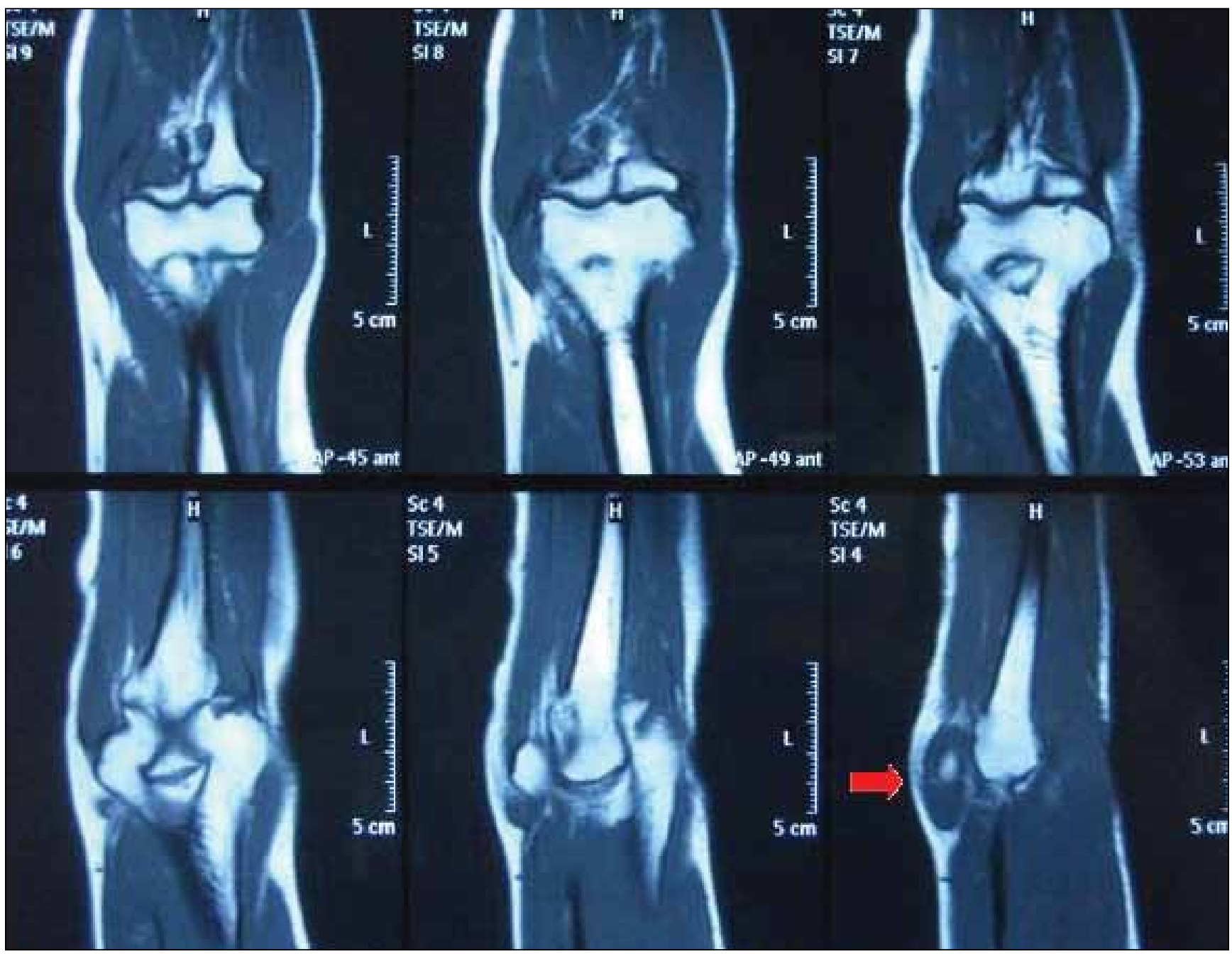

Figure 3: MRI view of the left elbow in coronal sections. The red arrow indicates the epitrochleoanconeus muscle.

Surgical Technique: Left ulnar nerve decompression surgery was performed under an axillary brachial plexus block with an upper arm tourniquet. The surgical field was exposed with a lazy $S$ shaped vertical incision $8 \mathrm{~cm}$ in length in the left ulnar region. An aberrant hypertrophic muscle (epitrochleoanconeus muscle) was observed instead of the Osborne ligament at its anatomical location. It extended from the olecranon through the medial epicondyle, in an oblique direction as defined in the MRI (Figure 4A-F). Just proximal to this muscle, the medial head of the triceps brachii muscle was more prominent extending over the cubital tunnel, covering the ulnar nerve lengthwise. The epitrochleoanconeus muscle was detached from the medial epicondyle and elevated. The ulnar nerve was compressed under that muscle and a sandglass deformity was observed (Figure 4A-F). The ulnar nerve was dissected proximally $8 \mathrm{~cm}$ through the Arcade of Struthers and distally $2 \mathrm{~cm}$ through the two heads of the flexor carpi ulnaris muscle. To avoid the subluxation, the nerve was transposed anteriorly from the epitrochleoanconeus muscle. The muscular fascia of the humeral head of the flexor carpi ulnaris muscle was incised in a step manner and the fascial flaps were elevated. Then the anteriorly transposed nerve was adapted under these fascial flaps and the fascial flaps were sutured to each other as in the Z-plasty technique to create a fascial roof wide enough not to compress the nerve (Figure 4). The muscle was left behind in its anatomical location without reattaching it to the medial epicondyle.

At the postoperative period, the arm was immobilized at $90^{\circ}$ flexion for 10 days postoperatively. Subsequently the patient was allowed to progressively begin full active range of motion. His complaints improved in the postoperative period.

\section{DISCUSSION}

The epitrochleoanconeus muscle was initially described by Wood in 1868, followed by LeDouble in 1897 (7). The incidence of identification of this muscle varies between $1 \%$ and $30 \%$ in cadaveric elbow studies (7). Various operative series of cubital tunnel syndrome have reported the epitrochleoanconeus muscle as an etiological factor of ulnar nerve compression with a varying range of $3.2 \%$ to $16 \%(4,7,14,19)$. The presence 

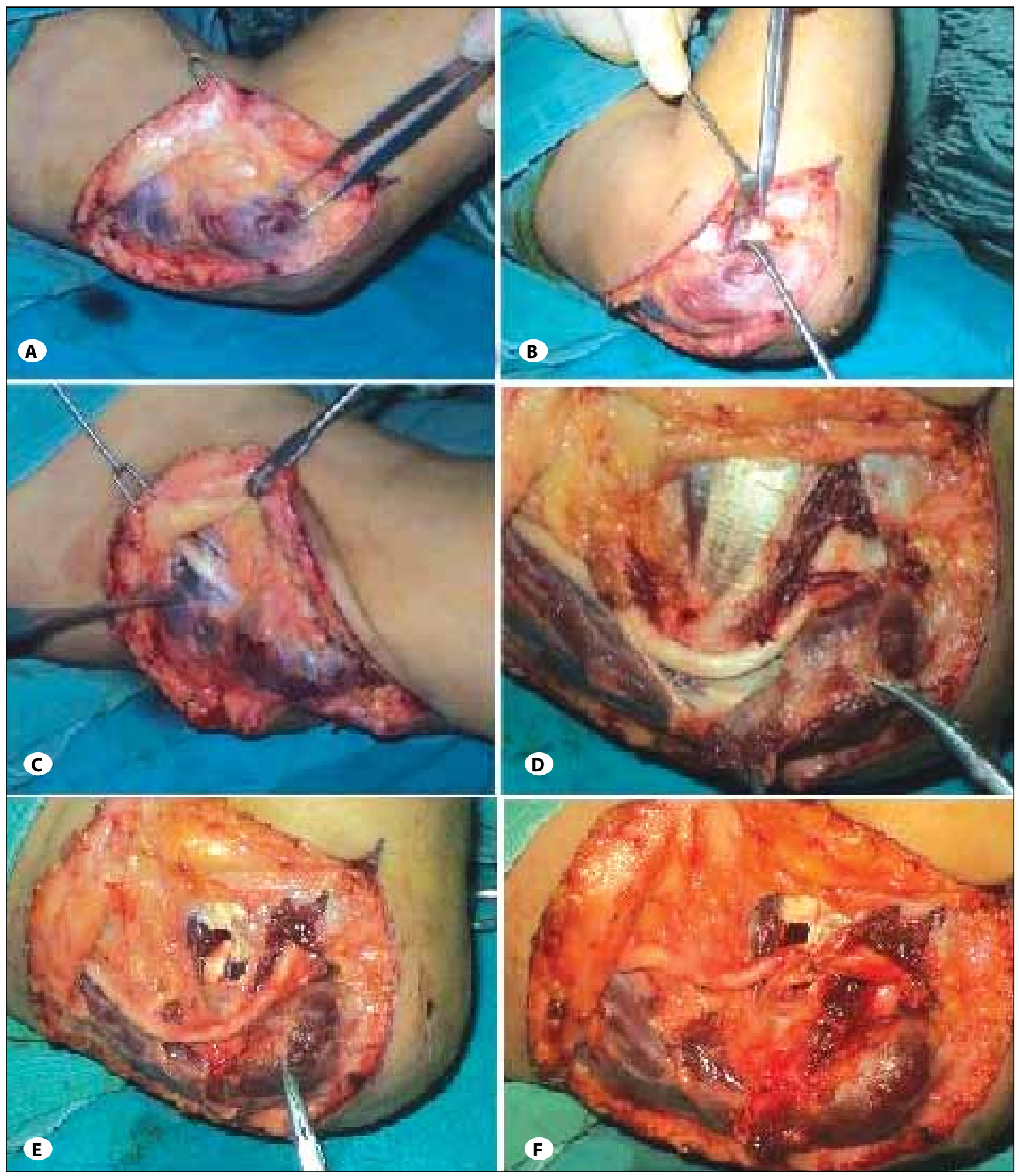

Figure 4: Peroperative view of left elbow region. A) Epitrochleoanconeus muscle, at the roof of the cubital tunnel. B) Ulnar nerve between two heads of flexor carpi ulnaris muscle. The nerve dissection was started from this region, in a distal to proximal direction. C) Ulnar nerve dissected from the prominent medial head of triceps brachii muscle proximally. D) Ulnar nerve in the cubital tunnel; the epitrochleoanconeus muscle was incised. E) The muscular fascia of the humeral head of the flexor carpi ulnaris muscle was incised in a step manner and the fascial flaps were elevated. F) Subfascial anterior transposition of the ulnar nerve to prevent subluxation. The transposed ulnar nerve was adapted under these fascial flaps and the fascial flaps were sutured to each other as in the Z-plasty technique to create a fascial roof wide enough not to compress the nerve. 
of this muscle is also reported to be usually associated with a prominent medial head of the triceps (6).

Either incision or excision of the epitrochleoanconeus muscle and the prominent portion of the medial head of the triceps with simple decompression of the ulnar nerve have been found effective as the surgical approach $(1,5,15$, $18,19)$. Anterior transposition of the ulnar nerve or medial epicondilectomy are the other less preferred techniques reported $(4,9,10,20)$. In order to avoid ulnar nerve subluxation after excision of the epitrochleoanconeus muscle, anterior subcutaneous transposition has been performed $(4,9,20)$. The authors who preferred medial epicondylectomy, aimed to prevent ulnar nerve irritation on the medial epicondyle after the removal of the epitrochleoanconeus muscle (10). However, this procedure was claimed to lead to persistent pain or heterotopic ossification. Submuscular transposition was therefore suggested as an alternative technique for ulnar nerve protection. The requirement for extensive tissue dissection and prolonged postoperative elbow immobilization are the disadvantages of this technique (7).

In the presented case, the epitrochleoanconeus muscle was dissected and incised from the attachment point on the medial epicondyle. The ulnar nerve was compressed under that muscle and a sandglass deformity was observed. The ulnar nerve was then dissected proximally through the Arcade of Struthers and distally through the two heads of the flexor carpi ulnaris muscle. Compression of the ulnar nerve was observed both under the epitrochleoanconeus muscle and through these structures. Complete dissection is important to prevent recurrent compressions (2). After complete dissection of the nerve, subluxation was inevitable, so anterior transposition of the nerve was required. A subfascial anterior transposition was preferred. The other alternatives were subcutaneous, intramuscular or the submuscular anterior transpositions. Intramuscular and submuscular transpositions are more complicated procedures necessitating extensive muscular dissection. Although these techniques place the nerve in a protected position, the necessity of long term immobilization and the potential complications such as excessive scarring especially in intramuscular transpositions and flexion contractures in submuscular anterior transpositions are disadvantages of these procedures $(2,12,13)$. Subcutaneous transposition is an easier surgical technique with less operative time and postoperative pain, earlier postoperative mobilization and better postoperative outcome as compared to the submuscular approach (11). Local tenderness especially in thin patients with deficient subcutaneous tissue and falling of the nerve backward are the undesired outcomes of this technique (2). Based on these points, the anterior transposition was performed through a noncompressive subfascial tunnel that places the nerve in a secure position, avoiding subluxation. In this technique the fascia band prevents the nerve from falling backward, holding it in a secure position. The procedure is easier to perform with shorter operative duration when compared to submuscular or intramuscular transpositions.
As an alternative opinion; extensive dissection so the requirement for anterior transposition or medial epicondylectomy is not suggested; if the ulnar nerve is observed to be compressed by the epitrochleoanconeus muscle and/or a prominent portion of the medial head of the triceps during the surgical exploration (7). Chalmers, mentioned the similarity of the anatomic location between the epitrochleoanconeus muscle and Osborne's ligament, accepted both as potential compressive agents for the ulnar nerve, and proposed removal of the epitrochleoanconeus muscle as adequate treatment (4). Removal of the prominent part of the medial head of the triceps, if necessary, was found not to compromise triceps function (17). However, if the nerve is dissected through proximally as in the presented case to prevent recurrent compressions because of unresected medial intermuscular septum or arcade of Struthers, to prevent the subluxation the choice of surgical approach is anterior transposition.

In conclusion, the epitrochleoanconeus muscle should be kept in mind as a rare cause of cubital tunnel syndrome. Subfascial anterior transposition might be accepted as a good surgical alternative to prevent subluxation after complete dissection of the ulnar nerve.

\section{REFERENCES}

1. Assmus $H$, Antoniadis $G$, Bischoff $C$, Hoffmann $R$, Martini AK, Preissler P, Scheglmann K, Schwerdtfeger K, Wessels KD, Wüstner-Hofmann M: Cubital tunnel syndrome - a review and management guidelines. Cent Eur Neurosurg 72(2):90-98, 2011

2. Black BT, Barron OA, Townsend PF, Glickel SZ, Eaton RG: Stabilized subcutaneous ulnar nerve transposition with immediate range of motion. Long-term follow-up. J Bone Joint Surg Am 82-A(11):1544-1551, 2000

3. Calisaneller T, Ozdemir O, Caner H, Altinors N: Simple decompression of the ulnar nerve at the elbow via proximal and distal mini skin incisions. Turk Neurosurg 21(2):167-171, 2011

4. Chalmers J: Unusual causes of peripheral nerve compression. Hand 10:168-175, 1978

5. Dahners LE, Wood FM: Anconeus epitrochlearis, a rare cause of cubital tunnel syndrome: A case report. J Hand Surg (Am) 9:579-580, 1984

6. Dellon AL: Musculotendinous variations about the medial humeral epicondyle. J Hand Surg (Br)11:175-181, 1986

7. Gervasio O, Zaccone C: Surgical approach to ulnar nerve compression at the elbow caused by the epitrochleoanconeus muscle and a prominent medial head of the triceps. Neurosurgery 62(3 Suppl 1):186-193, 2008

8. Gessini L, Jandolo B, Pietrangeli A, Occhipinti E: Ulnar nerve entrapment at the elbow by persistent epitrochleoanconeus muscle. Case report. J Neurosurg 55:830-831, 1981

9. Hirasawa Y, Sawamura H, Sakakida K: Entrapment neuropathy due to bilateral epitrochleoanconeus muscles: A case report. J Hand Surg (Am) 4:181-184, 1979 
10. Hodgkinson PD, McLean NR: Ulnar nerve entrapment due to epitrochleoanconeus muscle. J Hand Surg (Br) 19:706-708, 1994

11. Jaddue DA, Saloo SA, Sayed-Noor AS: Subcutaneous vs submuscular ulnar nerve transposition in moderate cubital tunnel syndrome. Open Orthop J 27(3):78-82, 2009

12. Janes PC, Mann RJ, Farnworth TK: Submuscular transposition of the ulnar nerve. Clin Orthop Relat Res 238:225-232, 1989

13. Leone J, Bhandari M, Thoma A: Anterior intramuscular transposition with ulnar nerve decompression at the elbow. Clin Orthop Relat Res 387:132-139, 2001

14. MacNicol MF: The results of operation for ulnar neuritis. J Bone Joint Surg (Br) 61B:159-164, 1979

15. O'Hara JJ, Stone JH: Ulnar nerve compression at the elbow caused by a prominent medial head of the triceps and an anconeus epitrochlearis muscle. J Hand Surg (Br) 21:133-135, 1996
16. Simsek S, Er U, Demirci A, Sorar M: Operative illustrations of the Osborne's ligament. Turk Neurosurg 21(2):269-270, 2011

17. Spinner RJ, O'Driscoll SW, Jupiter JB, Goldner RD: Unrecognized dislocation of the medial portion of the triceps: Another cause of failed ulnar nerve transposition. J Neurosurg 92:52-57, 2000.

18. Sucher E, Herness D: Cubital canal syndrome due to subanconeus muscle. J Hand Surg (Br) 11:460-462, 1986

19. Vanderpool DW, Chalmers J, Lamb DW, Whiston TB: Peripheral compression lesions of the ulnar nerve. J Bone Joint Surg (Br) 50:792-803, 1968

20. Wachsmuth W, Wilhelm A: The muscle epitochleoanconaeus and its clinical significance. Monatsschr Unfallheilkd Versicher Versorg Verkehrsmed 71:1-22, 1968 